\title{
Perspectives in Genomics
}

\section{The Future of Fungi in 'omics' era}

Fungi have been used for a long time as antibiotics and enzymes sources, major plant pathogens, and causing serious human diseases. Furthermore, there are different classes of fungi used as organisms model to study gene expression regulation as well as therapeutic proteins expression. Since the advent of fungal molecular biology (early of 1960s), new and large possibilities to explore the fungi as biotechnological agents has been increased. For that, fungal molecular biology use the DNA manipulation to achieve ideas from genetics and biochemistry, reaching the manipulation of metabolic pathways and producing new molecules to be used by humans.

\section{Fungi Diversity and Enzymes/antibiotics}

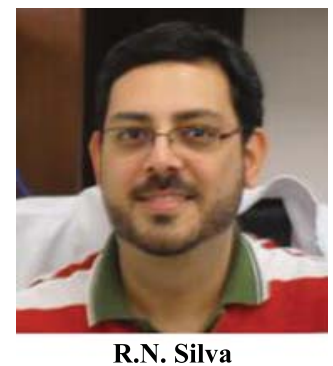

After antibiotics, enzymes are the most exploited molecules from fungi. In fact, fungi are interesting natural sources of biocatalysts since enzymes are applied to food industry, biomass hydrolysis, and therapeutic activity as well. The enzymes world market is around billions of dollars every year. Thus, the search for new molecules with catalytic characteristics as well as optimal conditions for industrial production is required. However, the wide range of classes of fungi in nature makes the screening for new enzymes a costly and expensive work. This way, genomics has grown to facilitate scientific research and reducing the number of steps and hence the biotechnological applications costs.

Currently, more than 500 fungal genomes are now available for public consultation (http://genome.jgi.doe.gov/ fungi/fungi.info.html). This includes industrial interest fungi such as Aspergillus niger [1] and Trichoderma reesei [2]; fungi able to cause plant diseases such as Fusarium graminearum [3], fungi that cause pathologies in humans such as Candida albicans [4] and Trichophyton rubrum [5], nevertheless fungi used as models organisms to study such as Saccharomyces cerevisiae [6] and Neurospora crassa [7].

A major problem in healthcare today is the antibiotic resistance. In part due to cross-resistance by indiscriminately antibiotics use, and another part to the selection and evolution of some strains of bacteria. As already mentioned, the fungi are major producers of antibiotics and the understanding of secondary metabolism of these organisms as well a possible genetic manipulation on large scale, should provide the production or biotransformation of new classes of antibiotics for clinical use.

\section{Fungi Plant Pathogens}

Agriculture has always played a prominent role in generating world's wealth. The production of world crops (soybeans, corn, wheat, rice and beans) will increase based on productivity. To achieve this goal, losses in crops should be minimized and most of these losses are attributed to pathogenic fungi that inhabit soils, which every year, millions of dollars are spent in their control. In world crops, infections caused by pathogens as Fusarium solani, Fusarium oxysporum, Sclerotium rolfsii, Rhizoctonia solani, and the fungus Sclerotinia sclerotiorum, cause losses of up to $100 \%$ in the production of susceptible crops. The main control strategy for these pathogens, worldwide applied, it is still the choice of chemical fungicides. This measure of control, though relatively efficient, it is a costly process, leads to the selection of resistant pathogens, and the emergence of secondary pests. In addition, the chemicals used are toxic and polluting and thus impact the environment and compromise the health of agricultural producers and consumers. In recent years, due to the pressure imposed by the laws of environmental impact, the growing concern of the population with the environment and health as well as the need to develop more efficient control methods, the demand arose for new strategies in this control. New alternatives to combat these pathogens are already used as biological control, which is based on the use of antagonistic microorganisms. This control can be direct, when the antagonists are applied directly into the living cultures, or indirect, by applying its metabolites. Hereby we should highlight the potential of Trichoderma species as biocontrol agents of infected plants.

\section{Human Fungal Pathogens}

There are about 1.5 million different species of fungi on Earth, but only about 300 of those are known to cause human diseases. Fungal diseases are often caused by fungi that are common in the environment, such as living in soil and on plants as well as on human skin.

Among the human pathogenic fungi, we highlight those who already have their genome unraveled. Candida albicans, that causes infection in individuals with deficient immune systems. Aspergillus fumigatus and Aspergillus flavus, which cause Aspergillosis and produce aflatoxin. Cryptococcus neoformans is the human pathogen that causes several form of meningitis and meningo-encephalitis in HIV infected patients and AIDS. Histoplasma capsulatum can cause histoplasmosis in humans, affecting primarily the lungs and other organs and may also affect AIDS patients because of their suppressed immunity. 


\section{Fungi and Genomics, Transcriptomics, Proteomics and Metabolomics: What Now?}

Fungal genomics is a science that deals with the discovery and characterizes all sequences in the entire genome. However, the determination of the genomic sequence is only the beginning of genomics. Once it is done, it is necessary to address a function of the numerous genes (functional genomics), compare the genes with other one organism (comparative genomics), study the expression profile (transcriptome), and finally to study the protein "expression profiling" (proteome) and the newest 'omics' sciences metabolomics as well as to refer to the complete study of low molecular weight compounds in the cell.

All the 'omics' science has provided a lot of information about fungal lifestyle and evolution, fungi-fungi interaction and fungi-environmental relationship. However, a huge amount of data has been generated and much single cell information has been lost. To avoid these losses, integrative information must be created to access the real status of fungal cells in response to some condition. This way now we have available an integrative approach calls System Biology.

Systems biology is the study of different aspects, which may evaluate diverse functions of cellular components, organisms as well as entire species. To achieve them, we use quantitative measurements such as genomics, proteomics, and mathematical and computational models (bioinformatics) to describe and predict dynamical behavior. Using this approach we can understand:

- Structure of the system

- Dynamics of the system

- Quantitative and qualitative analysis as well as construction of theory/model with prediction capability

- Regulation methods of the system

- Design methods of the system

Using high-throughput global data generated we can understand better the metabolism of fungi and how to improve them using metabolic engineer. However, this knowledge is just starting in omics science and we still have a long way to go.

That high-throughput must be used in the integrated methodologies in order to provide extensive knowledge about bioinformatics, fungal physiology and metabolism as well as differential skills in measuring gene and protein expression or interaction and metabolic flux analysis. This way, only researchers that works in a multidisciplinary approaching collaborative will be well succeed.

Based on this information, we can try to answer the question above 'What now?'

I have to say that the future of Fungi in 'omics' science is promising! As the metabolome and interactome as the metabolic fluxome will open new perspectives for the study of fungi and their application in biotechnology. For instance, we will understand better how the fungi evolved by years and how this evolution impacted the environment and our self. The scientists will predict how will be the evolution in the next years and will can interfere in this evolution. The medical mycology will use fungi as bioreactors for vaccine production or drug transformation. Fungi will be used as a vector for enzymes production to transform agriculture, food industry and biotechnology of biofuels production. We will understand better how is the interaction as foes or as friends of fungi in our organism. The crops production will be improved with the understanding and genetic manipulation of fungi to interact with plants. Finally, we will use the fungal models organisms to predict the interaction of different proteins to be used as biotechnological application and lower the production cost of many important molecules to medicine usage. So, face with that, be prepared!

\section{REFERENCES}

[1] Andersen, M.R.; Salazar, M.P.; Schaap, P.J.; van de Vondervoort, P.J.; Culley, D.; Thykaer, J.; Frisvad, J.C.; Nielsen, K.F.; Albang, R.; Albermann, K.; Berka, R.M.; Braus, G.H.; Braus-Stromeyer, S.A.; Corrochano, L.M.; Dai, Z.; van Dijck, P.W.; Hofmann, G.; Lasure, L.L.; Magnuson, J.K.; Menke, H.; Meijer, M.; Meijer, S.L.; Nielsen, J.B.; Nielsen, M.L.; van Ooyen, A.J.; Pel, H.J.; Poulsen, L.; Samson, R.A.; Stam, H.; Tsang, A.; van den Brink, J.M.; Atkins, A.; Aerts, A.; Shapiro, H.; Pangilinan, J.; Salamov, A.; Lou, Y.; Lindquist, E.; Lucas, S.; Grimwood, J.; Grigoriev, I.V.; Kubicek, C.P.; Martinez, D.; van Peij, N.N.; Roubos, J.A.; Nielsen, J.; Baker, S.E. Comparative genomics of citric-acid-producing Aspergillus niger ATCC 1015 versus enzyme-producing CBS 513.88. Genome Res., 2011, 21(6), 885-97.

[2] Martinez, D.; Berka, R.M.; Henrissat, B.; Saloheimo, M.; Arvas, M.; Baker, S.E.; Chapman, J.; Chertkov, O.; Coutinho, P.M.; Cullen, D.; Danchin, E.G.; Grigoriev, I.V.; Harris, P.; Jackson, M.; Kubicek, C.P.; Han, C.S.; Ho, I.; Larrondo, L.F.; de Leon, A.L.; Magnuson, J.K.; Merino, S.; Misra, M.; Nelson, B.; Putnam, N.; Robbertse, B.; Salamov, A.A.; Schmoll, M.; Terry, A.; Thayer, N.; Westerholm-Parvinen, A.; Schoch, C.L.; Yao, J.; Barabote, R.; Nelson, M.A.; Detter, C.; Bruce, D.; Kuske, C.R.; Xie, G.; Richardson, P.; Rokhsar, D.S.; Lucas, S.M.; Rubin, E.M.; Dunn-Coleman, N.; Ward, M.; Brettin, T.S. Genome sequencing and analysis of the biomass-degrading fungus Trichoderma reesei. Nat. Biotechnol., 2008, $26,553-560$.

[3] Cuomo, C.A.; Güldener, U.; Xu, J.R.; Trail, F.; Turgeon, B.G.; Di Pietro, A.; Walton, J.D.; Ma, L.J.; Baker, S.E.; Rep, M.; Adam, G.; Antoniw, J.; Baldwin, T.; Calvo, S.; Chang, Y.L.; Decaprio, D.; Gale, L.R.; Gnerre, S.; Goswami, R.S.; Hammond-Kosack, K.; Harris, L.J.; Hilburn, K.; Kennell, J.C.; Kroken, S.; Magnuson, J.K.; Mannhaupt, G.; Mauceli, E.; Mewes, H.W.; Mitterbauer, R.; Muehlbauer, G.; Münsterkötter, M.; Nelson, D.; O'donnell, K.; Ouellet, T.; Qi, W.; Quesneville, H.; Roncero, M.I.; Seong, K.Y.; Tetko, I.V.; Urban, M.; Waalwijk, C.; Ward, T.J.; Yao, J.; Birren, B.W.; Kistler, H.C. The Fusarium graminearum genome reveals a link between localized polymorphism and pathogen specialization. Science, 2007, $317(5843), 1400-2$.

[4] Jones, T.; Federspiel, N.A.; Chibana, H.; Dungan, J.; Kalman, S.; Magee, B.B.; Newport, G.; Thorstenson, Y.R.; Agabian, N.; Magee, P.T.; Davis, R.W.; Scherer, S. The diploid genome sequence of Candida albicans. Proc. Natl. Acad. Sci. U. S. A., 2004, 101, 7329-34.

[5] Martinez, D.A.; Oliver, B.G.; Gräser, Y.; Goldberg, J.M.; Li, W.; Martinez-Rossi, N.M.; Monod, M.; Shelest, E.; Barton, R.C.; Birch, E.; Brakhage, A.A.; Chen, Z.; Gurr, S.J.; Heiman, D.; Heitman, J.; Kosti, I.; Rossi, A.; Saif, S.; Samalova, M.; Saunders, C.W.; Shea, T.; Summerbell, R.C.; Xu, J.; Young, S.; Zeng, Q.; Birren, B.W.; Cuomo, C.A.; White, T.C. Comparative genome analysis of Trichophyton rubrum and related dermatophytes reveals candidate genes involved in infection. MBio., 2012, 3(5), e00259-12. 
Engel, S.R.; Dietrich, F.S.; Fisk, D.G.; Binkley, G.; Balakrishnan, R.; Costanzo, M.C.; Dwight, S.S.; Hitz, B.C.; Karra, K.; Nash, R.S.; Weng, S.; Wong, E.D.; Lloyd, P.; Skrzypek, M.S.; Miyasato, S.R.; Simison, M.; Cherry, J.M. The Reference Genome Sequence of Saccharomyces cerevisiae: Then and Now. G3: Genes|Genomes|Genetics. 2014, 4(3), 389-398.

[7] Galagan, J.E.; Calvo, S.E.; Borkovich, K.A.; Selker, E.U.; Read, N.D.; Jaffe, D.; FitzHugh, W.; Ma, L.J.; Smirnov, S.; Purcell, S.; Rehman, B.; Elkins, T.; Engels, R.; Wang, S.; Nielsen, C.B.; Butler, J.; Endrizzi, M.; Qui, D.; Ianakiev, P.; Bell-Pedersen, D.; Nelson, M.A.; Werner-Washburne, M.; Selitrennikoff, C.P.; Kinsey, J.A.; Braun, E.L.; Zelter, A.; Schulte, U.; Kothe, G.O.; Jedd, G.; Mewes, W.; Staben, C.; Marcotte, E.; Greenberg, D.; Roy, A.; Foley, K.; Naylor, J.; Stange-Thomann, N.; Barrett, R.; Gnerre, S.; Kamal, M.; Kamvysselis, M.; Mauceli, E.; Bielke, C.; Rudd, S.; Frishman, D.; Krystofova, S.; Rasmussen, C.; Metzenberg, R.L.; Perkins, D.D.; Kroken, S.; Cogoni, C.; Macino, G.; Catcheside, D.; Li, W.; Pratt, R.J.; Osmani, S.A.; DeSouza, C.P.; Glass, L.; Orbach, M.J.; Berglund, J.A.; Voelker, R.; Yarden, O.; Plamann, M.; Seiler, S.; Dunlap, J.; Radford, A.; Aramayo, R.; Natvig, D.O.; Alex, L.A.; Mannhaupt, G.; Ebbole, D.J.; Freitag, M.; Paulsen, I.; Sachs, M.S.; Lander, E.S.; Nusbaum, C.; Birren, B. The genome sequence of the filamentous fungus Neurospora crassa. Nature, 2003, 422(6934), 859-68.

Roberto N. Silva

Guest Editor Department of Biochemistry and Immunology Ribeirão Preto Medical School, University of São Paulo 14049-900 Ribeirão Preto, SP

Brazil 